\title{
Generational differences in consumption patterns in Hungary
}

\section{Agnes Hofmeister-Toth* and Agnes Neulinger}

\author{
Department of Market Research and Consumer Behaviour, \\ Corvinus University of Budapest, \\ Fővám tér 8., Budapest 1093, Hungary \\ Fax: +3614825236 \\ E-mail: agnes.hofmeister@uni-corvinus.hu \\ E-mail: agnes.neulinger@uni-corvinus.hu \\ *Corresponding author
}

\begin{abstract}
Various authors have used the term consumer society with a number of different meanings, yet one common point has been the shift of focus to the consumer ethos, which alters the everyday life of society members and their relationship to each other and society as a whole. One's relationship to consumption determines fundamental levels of consumption and for what purposes (e.g. hedonic values, family and savings), thus it is essential to explore this relationship to develop an understanding of consumer behaviour and to create effective marketing messages. This paper provides a brief summary of the various approaches and research lines of consumer culture and reviews the findings of the first, qualitative phase of our consumer culture study in Hungary. The purpose of this research programme is to analyse the changes in people's relationships to consumption since the change of regime.
\end{abstract}

Keywords: consumer behaviour; values; consumer society; legitimate consumption; purchase decision; shopping; consumption patterns; generations; business research.

Reference to this paper should be made as follows: Hofmeister-Toth, A. and Neulinger, A. (2011) 'Generational differences in consumption patterns in Hungary', Int. J. Economics and Business Research, Vol. 3, No. 1, pp.118-130.

Biographical notes: Agnes Hofmeister-Toth is the Dean in the Faulty of Business Administration at the Corvinus University of Budapest. She received her PhD in Marketing from BUESPA. She spent periods as a Visiting Professor at several universities abroad, such as Haas School University of Berkeley, Hosei University Tokyo, Northwestern University, London Business School, etc. She is teaching Consumer Behavior and Negotiation. Her research interests are cultural differences, transition of consumer behaviour, changing consumer values and symbolic consumption. She is the Author of a great deal of research studies published at national and international journals as well.

Agnes Neulinger is an Assistant Professor at Corvinus University of Budapest. Upon graduating in 2000, she started her career at Corvinus University of Budapest. She moved to business sector and became Consumer Research Executive in British American Tobacco Hungary in 2004, than in media sector in Ringier Hungary as Senior Market Researcher in 2006. She returned to the university education in 2008. She gives lectures on marketing research and consumer behaviour for BA and MA courses. She regularly participates in and leads research projects. Her main research interests are household consumption and research methodology.

Copyright (C) 2011 Inderscience Enterprises Ltd. 
Present study is part of the OTKA-supported (KO-5558/2006) research program, 'The process of consumer socialisation in Hungary'.

\section{Introduction}

One of the most popular topics in consumption research is the birth of and current developments in consumer culture, with consumer socialisation being one of the most important aspects. Consumer culture is not merely a quantitative phenomenon: beyond the fact that there are more consumers (among numerous layers of society) consuming more goods, a qualitative change in the social role of consumption is also taking place. Thus the study of consumer culture necessitates something more than just an analysis of macro-level consumption indices and economic-political changes: we need to evaluate the extent to which consumption influences the everyday lives of members of society and their relationships to each other and society as a whole. Earlier Hungarian studies on the topic basically applied a macro approach and focused on a single element (e.g. shopping malls) of the consumer environment. Our study, on the contrary, examines subjective attitudes, opinions and experiences related to consumption; we aim to explore how the system of norms in consumer society is internalised and how consumer society forms at the level of the individual.

The purpose of this research project is to develop an understanding of the evolution process of consumer society in Hungary and to formulate forecasts concerning possible future developments. The time has come for such a research study: there is already a generation of young adults who have been in contact with the Western consumer culture ever since their early childhood; their relationship to consumption has formed in this socialisation environment. We still have the opportunity to include in the research members of the elder generation who were educated according to the socialist system of values, which deemed people's desires for various goods and individual consumption to be inappropriate. These two generations cannot be clearly distinguished as consumer culture has been gradually gaining ground since the 1970s due to the continuous improvement in the standard of living and the leaking-in of Western goods in evergrowing amounts (Hammer and Dessewffy, 1997; Nagy, 1997; Wessely, 2000).

The alignment of these two generations and systems of values offers a unique research opportunity as the evolution of consumer culture can directly be observed, whereas Western studies rarely rely on anything other than secondary sources.

\section{The consumer society}

The term consumer society is widely used both in social sciences literature and in everyday language. Several authors use the terms consumer society and consumer culture as synonyms. Although their meanings do overlap to some extent, the two concepts are different both in terms of approaches and subjects of analysis. The term consumer society basically emphasises the social nature of the differences between today and past eras. Consumer culture, however, underlines the role of lifestyles, values and subjective interpretations of the world. This approach has its roots in cultural anthropology. 
The term culture refers to the common values, shared world view and the specific way of life of a given group or society (Douglas and Isherwood, 1996). The essence of culture, according to this approach, is that participants share a common interpretation of the surrounding world.

In Western Europe and in the USA, the past couple of decades have witnessed the transition of consumption research into a separate subdiscipline of social sciences (Ritzer and Slater, 2001). One of the most popular consumption research topics is the evolution of and current developments in consumer culture, with consumer socialisation being a key element.

The growing number of household and lifestyle studies completed in Hungary since the 1970s called attention to the close relationship between consumption and values: "the shift in society's lifestyle, way of life and attitude to life during the seventies was a shift towards consumer behavior, and material goods occupy a very high rank within people's hierarchy of values" (Nagy, 1997, p.47). Findings of several studies support the notion that some characteristics of the 'Western consumer' appeared in the Eastern bloc during the socialist era: primarily consumer desires, the symbolic perception of goods and the growing role of goods in the development of one's identity.

A study of special importance to the topic is a 1996 interdisciplinary project of researchers from Romania, Yugoslavia, Croatia, Slovenia and Hungary titled 'Culture with boundaries: shopping tourism and travelling objects in post-World War II Middle Europe' ('Kultúra határokkal: bevásárló turisták és utazó tárgyak a II. világháború utáni Közép-Európában'), which examined the effect on the inflow of Western objects and ideas on the process of socialisation in the consumer society and on the formation of local identities (Wessely, 2000). Findings showed that in the countries mentioned, a unique (limited and somewhat distorted) consumer society was formed. Dessewffy (2002) analysed the discussion of the 'appropriate amount of consumption' by using content analysis. Results implied that the legitimate extent of desires constituted a central element of the discussion on consumption in socialist Hungary. Officially, two types were distinguished: the satisfaction of real needs and the kind of consumption that turns into personal property, which was centrally supported as opposed to false needs or private property, which was disapproved. Although the consumption of goods from the former category was expressly supported (in practical terms, as well), the range and the number of these were precisely limited (Dessewffy, 2002). One sign of the strengthening of consumer legitimacy was that after the revolution, consumption became one of the primary means by which to come to terms with society: for political passivity, in return, the regime agreed to leave the sphere of everyday life, to ensure a certain degree of freedom of consumption and improvements in the standard of living.

Conclusions concerning the changes in the social role of consumption can be based on the lifestyle studies performed since the change of regime (see Hofmeister-Tóth, 2004; Hofmeister-Tóth and Töröcsik, 1998, etc.) and on the surveys of a number of market research firms. Findings imply that a lifestyle-based classification of society provides a basis for reliable forecasts, which suggests that the role played by consumption in society is constantly growing in importance.

In terms of consumer values, the socialist system (altruism, acting for the good of the community, interest in culture, etc.) reflects a postmaterialist orientation (Keller and Vihalemm, 2003). According to data from World Value Surveys, however, there was a strong shift towards materialist values in former socialist countries after the change of regime, which also holds true for Hungary (Hofmeister-Tóth, 2004). Most likely, this is 
partly due to the success of the market economy, competition and private enterprise and partly to the obligatory system of values of the socialist regime's disappearance. The change of regime, nevertheless, also brought about the streaming in of Western culture such that former socialist countries now witness the resurrection of the postmaterialist system of values characteristic of the West, primarily among youth who are more open to new ideas (Toomere, 2001, as cited in Keller and Vihalemm, 2003).

\section{Approach and research purpose}

Three typical approaches of consumer society are present in literature. The first emphasises quantitative indices and its analyses focus on the expansion of individual consumption (especially that of global products, e.g. Coca Cola), shopping malls and marketing activities. The majority of historical studies and ecology-oriented analyses belong to this category, as well as writings that only scratch the surface of the topic and use consumer society rather as a journalistic concept.

The second approach considers the enhanced use of individual consumer logic to be the main point: in consumer culture, "Core social practices and cultural values, ideas, aspirations and identities are defined and oriented in relation to consumption rather than to other social dimensions such as work or citizenship, religion or military role" (Slater, 1997, p.24). One of the related research lines explores how consumer logic transforms formerly state-provided services, such as healthcare, education and culture. Another line deals with the role of consumption in self-definition: to what extent are life purposes and identities determined in relation to consumption?

The third stream puts forth the idea that in consumer culture, insatiable desires are considered not only normal but also necessary conditions for social and economic development. A fundamental transformation of values is believed to be in the background of changes: hedonic values (spending, buying on credit and present-orientation); rapid obsolescence and the variation of styles take precedence over former puritan values (e.g. savings, future-oriented planning and reserving goods for later). In a consumer society, according to Bauman (2001), the boundary between luxury and everyday gets blurred, as, even in theory, experience and delight become the purposes of consumption instead of the satisfaction of needs: thus a discussion on the appropriate amount of consumption is senseless.

As our study aimed to explore changes at the level of the individual, questions were formulated that relied primarily on the second and the third approach. Our assumption was that different generations were exposed to different socialisation processes such that their comparison offers the opportunity to observe how consumer culture has changed over time. Changes are analysed along the following dimensions:

1 Relationship of consumption with self-definition and life purposes

a What is the role of consumption in formulating one's life purposes?

b What is the role of consumption in self-definition?

2 Limits of legitimate consumption

c Which purposes and values are used to justify consumption decisions? 
d What amount of consumption is considered acceptable by the various social groups, and is there a consensus on the legitimate extent of desires?

3 Change in the relationship to consumption

e To what extent was the change of regime perceived as a transformation to a consumer society?

f How have consumption-related attitudes, perceptions and opinions changed since the change of regime?

A two-phase method that employed both qualitative and quantitative methods was developed to answer the above questions.

The purpose of the qualitative phase was to develop a thorough understanding of the process of consumer socialisation and a comprehensive exploration of individual experiences and opinions. Based on the findings, a questionnaire survey was completed to analyse the distribution of the various opinions and consumer types among Hungary's population. Below, we provide an overview of the qualitative phase.

The transformation of people's relationships to consumption is analysed by examining generational differences. The observation of multigenerational families is the most suitable method for this purpose as influences from external factors can be minimised by this way. The sampling criterion was the presence of two or more generations, with the first, second and third generations having been born before 1939, 1969 and 1990, respectively. This ensures that the sample includes both elder participants who lived the majority of their lives during the socialist era and younger people who have only experienced the market economy. The qualitative phase relies on three methodological elements, all of them applied to all three generations of the families. The social and historical context of the transformation of people's relationship to consumption were explored employing episodic interviews. This technique is a type of oral history developed primarily for the examination of group-specific differences (Flick, 2002, 2005). Results of earlier studies (Ger and Belk, 1999; Miller, 1999) implied that this method reveals general attitudes towards consumption; everyday purchase experiences are less frequently mentioned. It is important, however, also to analyse consumption in the context of everyday practices, therefore our methods also included observation of participant purchases. Neither episodic interviews nor a narrative approach have been used previously in Hungary. The large-scale participant observation of purchase decisions in an everyday context also constitutes a novelty, as the majority of earlier studies instead used inquiries. Another special feature of our project is the simultaneous application of the various techniques, each underlining a different aspect of the research questions and the comparison of the data supplied by the different methods, which enabled us to draw conclusions about the validity of our findings.

\section{Fieldwork and sample}

The sample of the qualitative phase ultimately included 15 families with 45 respondents altogether. The diversity of the sample was ensured by varying the income class and the place of residence of the participants, both of which were presumed to exert an important influence on the questions examined. Interviews were conducted in Györ, Pásztori, Kaposvár, Kecskemét, Budapest, Pásztó, Ózd, Szerencs, Hajdúszoboszló, Debrecen, 
Vásárosnamény and Klézse (Romania). The desired variance in per capita income was achieved by reviewing in advance the demographic characteristics of the sample families. Qualitative surveys were conducted by the research leader and her research assistants, whereas data entry (computerised recording of audio material) was completed with assistance from fifth-year university students with majors in marketing. For the analysis of qualitative data, we used the content analysis software Atlas ti.

\section{Research findings}

\subsection{Associations related to the expressions consumption/shopping}

Associations related to consumption and shopping generally remained on the level of basic needs, and the activities primarily associated with them - food or clothing purchases - also aimed at satisfying such needs. Considering generational differences, most younger respondents mentioned 'money' or 'spending money', whereas the middle generation already associated the family, the satisfaction of the family's needs and budgeting and the planning of financial resources to the concepts in question. In case of the eldest generation, economisation and the fulfilment of the most basic needs were characteristic, along with the 'lack' of shopping or consumption has been mentioned several times, which might be in connection with the absence of (e.g. weekly) large shopping trips. Responses typical for each generation were:

Younger generation: "Fulfillment of some need. Spend a lot of money. Food, drinks, perfumes".

Middle generation: "To me, shopping means one of those necessary, repeated, routinelike household tasks".

Elder generation: "In old times? Because we do not really go shopping lately. We do not belong to that group any more, do we? Pensioners". Or: "Well, people spend their money much easier now than back in the old days. Then, when we were young, you didn't just buy a couple of kilos of something, no, it was 100 grams or 200 grams or so".

The majority of respondents did not associate any emotions with these concepts but considered shopping and consumption as evident: "That's life, you simply need to buy things. Consumption is inevitable, it provides enough, food, clothing, you have to buy pretty much everything you cannot produce yourself'. A couple of responses, however, relayed a clearly identified negative or positive message; the summary of these is presented in the table below.

\begin{tabular}{lrrrrr}
\hline & \multicolumn{4}{c}{ Generations } \\
\cline { 2 - 5 } Associations & & $I I$ & $I I I$ & $\sum$ \\
\hline Negative associations & 3 & 5 & 2 & 10 \\
Positive associations & 4 & 2 & 1 & 7 \\
Neutral & 8 & 8 & 11 & 27 \\
Total & 15 & 15 & 14 & 44 \\
\hline
\end{tabular}


Interestingly, this implies that emotional associations related to consumption and shopping seem to be of a negative nature. Respondents connected these concepts to a kind of compulsive necessity: what appears is compulsion, intemperance, time expenditure, the denial of consumption/shopping-based identities, overconsumption and over expenditure. Positive emotional associations included spare time, recreation, care and the love for shopping. Responses typical for each generation were:

Younger generation: "My relationship to clothes shopping, to spending money is a schizophrenic one. I like shopping for clothes, but at the same time I do also know that one should not built his/her identity on that".

Middle generation: "Consumption, you know, has a kind of pejorative meaning to me, since if you try to rationalize your expenditures, as I try to do, and you do one big shop in a month, and you go to one of these crazy big malls, well, there are so many objects of desire there that you just simply cannot avoid overconsuming and needlessly spending your money. This duality of rationalization and a call for some kind of lightheadedness, this is consumption".

Elder generation: "Frankly speaking, I do not really like shopping, but it's still a must".

\subsection{Individual experiences related to consumption and shopping}

\begin{tabular}{lrrrrr}
\hline & \multicolumn{4}{c}{ Generations } \\
\cline { 2 - 5 } & & $I$ & $I I$ & $I I I$ & $\sum$ \\
\hline Adulthood & 1 & 4 & 7 & 12 \\
Childhood & 10 & 10 & 4 & 24 \\
Adolescence & 3 & 4 & 0 & 7 \\
Total & 14 & 18 & 11 & 43 \\
\hline
\end{tabular}

It is apparent that for members of the elder generation, the first consumption and shopping-related experiences typically happened during adulthood, which might be a consequence of the supply shortages characteristic of their childhoods, as also implied by some of the responses.

"My very first experience dates back to around 1948, as we were queuing from 7 o'clock in the afternoon in front of a garment store because they said that a shipment of winter coats would arrive the next morning and that we could then buy one. That's were we stood, right in the queue, all night long, and the store opened in the morning, the coats arrived and believe it or not, as early as around 10-11 o'clock we became proud owners of a new winter coat."

First experiences usually included clothing items or excise goods; only a small portion related to consumer durables or food items. 


\begin{tabular}{lrrrr}
\hline & \multicolumn{3}{c}{ Generations } \\
\cline { 2 - 5 } Categories & $I$ & $I I$ & $I I I$ & $\sum$ \\
\hline Basic food & 0 & 3 & 2 & 5 \\
Food & 0 & 1 & 1 & 2 \\
Excise goods & 7 & 3 & 2 & 12 \\
Clothing & 6 & 7 & 3 & 16 \\
School equipment & 0 & 1 & 0 & 1 \\
Consumer durables & 1 & 3 & 4 & 8 \\
Total & 14 & 18 & 12 & 44 \\
\hline
\end{tabular}

The share of excise goods is highest among the young generation, but clothing was also frequently mentioned. The middle generation typically mentioned sweets, chocolates and candies. Members of the third generation mentioned consumer durables (e.g. automobiles, motorbikes and refrigerators) several times, the purchase of which meant a kind of experience to respondents because "that was really something in those days". The most memorable experiences happened during adulthood with the share of consumer durables becoming higher. The first experiences of the youngest generation tended to be in connection with autonomy and shopping on their own. The majority of respondents mentioned experiences that included products that they had desired and for which they had collected the money (e.g. sweets, clothing and consumer electronics). Experiences of the third generation, surprisingly enough, are not related to giving up things but rather to the purchase of clothing and consumer durables, which constituted a rare 'event' for the whole family.

\subsection{Purchases beyond basic needs and impulsiveness}

Concerning purchases beyond basic needs, the three generations exhibited significant differences: based on the responses, we concluded that purchases beyond basic needs are far more characteristic for the young and the middle generations than for older people. Interestingly, responses also differed by gender: males reported that they paid far more attention to what they bought and that they did not purchase anything beyond their basic needs or only did so rarely. This might be partly explained by the fact that males tend to go shopping less frequently and that consumer electronics have a more important share in their purchases. Males in this study were not characterised by misguided purchases (e.g. "I am sober-minded; I only buy what is needed") or a weaker financial situation kept them from purchasing anything beyond basic needs. Based on the respondents' answers, we believe that there are now more people making purchases beyond their basic needs, which clearly implies that after all, we tend to buy more.

\begin{tabular}{lcccc}
\hline & \multicolumn{4}{c}{ Generations } \\
\cline { 2 - 5 } Frequency & $I$ & $I I$ & $I I I$ & $\sum$ \\
\hline Often & 9 & 5 & 2 & 16 \\
Rarely & 3 & 8 & 5 & 16 \\
Not characteristic & 3 & 2 & 7 & 12 \\
Total & 15 & 15 & 14 & 44 \\
\hline
\end{tabular}


Impulsiveness has an important role in purchases beyond basic needs that also was clearly identified in some of the responses. Further investigation of impulsive respondents' answers prompted us to conclude that shopping means something more than a pastime, and it is interrelated with one's mood and emotional state of mind. Several people mentioned that 'shopping is a source of joy', 'you heal yourself by going shopping' and shopping 'relieves stress caused by the exams' and pampering, rewarding was also present, '.... a reward on salary day'. Some also reported that they felt a kind of inner urge to buy something: "It felt definitely like an inner urge that I just have to buy something" or "I have an addiction lately: I buy secondhand clothes, and I do it rather maniacally". Food, clothes, books and small gadgets were mentioned most frequently, all of which can be considered cheap or average-priced items. Another observation was that the objects mentioned by the second and the third generation usually represented a higher value (e.g. bicycles, tape recorders, chinaware, paintings and cameras).

\subsection{The role of consumption today and in the past}

Nearly all of the respondents meant that consumption and shopping have much more significant role now than it once had. No generational difference was observed concerning this matter; negative associations were rather frequent, which may primarily be the consequence of overconsumption and the abundance of goods.

Concerning the consumption and shopping patterns of middle generation, emphasis was on shopping malls and regular (e.g. weekly), large shopping trips. Several respondents mentioned that shopping became a family programme: "We have huge malls. These opened up new opportunities in people's lives, and many like to go to these shopping malls instead of spending their time at home with the neighbors, friends, relatives or with anything else". They believed that

"As I have a job in a school, I often hear children telling each other that the weekend program of the family was that we went shopping to Tesco's or Auchan's. On these occasions, parents buy a lot of things children like, say potato chips or beverages; pretty often they even have their family meal there."

The abundance of goods, with advertisements and sales encouraging people to buy things beyond their basic needs, was mentioned by this generation, as well.

More people from the elder generation mentioned the lack of self-produced goods, the growth both in people's needs and in the supply of goods and that 'there are many more tempting offers' today. It seems that to the respondents, the enhanced role of consumption and shopping usually meant an increase in the amount of goods purchased: 'we became slaves to objects' and 'people overconsume'.

\subsection{The influence of consumption/shopping patterns on social relationships}

The majority of respondents reported that their judgement of their relationships with others was not typically based on consumption/shopping habits. Interestingly, for all three generations, the first sentence of respondents' answers often included something like "I don't think I judge people according to that, no, nobody".

Members of the younger generation firmly insisted that their relationships had not been influenced by their consumption/purchases. For the majority, consumption was not 
the basis by which they judged their relationships with others. They said that this might originate in their friends and acquaintances having a similar taste.

The determining role of one's company was especially apparent in the case of young respondents: "I tried to always remain on the same level as my friends; we always tried to buy similar things, yet we did not buy the exact same stuff" or "The people around me enjoy more or less the same standard of living as me. Thus envy or jealousy is not a problem for us".

The second generation, however, was somewhat less homogenous. About 9 out of 15 respondents believed that changes of this kind did actually happen. Differences in people's financial situations seemed to have come to the foreground, causing conflicts, breaking off friendships and changing social relationships. Respondents demonstrated a certain degree of envy for those 'who have it made' and had suddenly become rich.

The third generation, once again, was not influenced by differing consumption patterns in their relationships with others:

"Certainly, my neighbor might have a Mercedes Benz, very nice, yet that Mercedes does not necessarily make them any more valuable than me. Yes, they might be trying to become a member of the upper class, but that car just takes them to the very same place as my Opel does it for me."

\subsection{The limits of legitimate consumption}

Having reviewed the responses, we concluded that respondents were quite divided concerning the matter and that they did not really even understand the question. Most of them thought of some kind of a quantitative limit, which they identified with their disposable income. The majority interpreted the question on the individual's level and there was no consensus concerning the answer. Some mentioned limits determined by one's financial background, whereas others used the very same argument to support their idea that such limits do not exist: "I don't think there is. You spend as much as you think you can afford. And if you can afford a Rolls Royce instead of a Trabant, well then go ahead. I don't think there's anything wrong with that". After all, more than half of the respondents meant that there were no such limits. Individual consumption opportunities are only limited by one's income.

A couple of respondents from the second generation explained that some kind of limit would be absolutely necessary, yet they believed that it did not exist and that it would never come into being, either: "If someone gets something, they always want more" or "I do n't think there is, but there should be, such that people do not use consumption to compensate for a whole lot of other things". The majority of those who meant that there is a limit to consumption and shopping thought that it was somehow related to basic needs (and disposable income). Some of them suggested that "If you eat out in a fancy restaurant or use an expensive car, wear expensive, markedly expensive clothes, elegant clothes, that can be showy on its own, and it can, thus it can awaken a kind of repulsion" or "If we are talking about socially acceptable limits here, we can say that if one buys some luxury car, they may want to use it to display their social position. And people are offended by that". They associated the limits on consumption with how much it differs from the average and to what extent it is accepted by society. Interestingly, respondents hardly ever mentioned limits of a qualitative nature (environment, health, etc.). 


\subsection{People consume too much nowadays}

The majority agreed with the statement that people consume too much, yet they provided different explanations that originated in various individual and environmental factors. A number of respondents considered overconsumption and the consumption of unnecessary things to be the same or at least very similar concepts. Several participants stated that people buy far more products than what they actually need. Some said as an obvious example, "You should have a look into people's trash bins". Respondents blamed the wide choice and the abundance of goods for people's overconsumption.

At the same time, some people from the second and the third generations mentioned that nowadays 'We spend more because we have more' or 'people spend a lot, they live a better life than in the past'. The majority of respondents believed that overconsumption is the result of the effects of the media and advertising, which 'use our subconscious to make us believe we have to buy that by all means' or 'ads are everywhere, in the TV, on the streets, on posters, plastic bags, buses, walls, simply everywhere. And ads can have a terribly strong influence on people". Self-expression and accumulation from consumption and shopping were mentioned as individual factors. 'A lot of people express themselves through their consumption patterns, thus they own various status symbols; for them, it is consumption that makes them feel that they belong to a certain group'. 'A certain urge to accumulate has evolved'.

The majority of respondents think that people nowadays consume unnecessary things. What they basically meant was in this case, however, food items: 'this is a curse of civilisation, we overfeed ourselves, we eat and drink far too much'. Nonetheless, health and healthy diets were also mentioned, primarily by members of the second generation: "Oh, yes, we do, we do consume unnecessary things. Especially things which might even harm our health" or "We consume a whole lot of fast food, ready-to-eat food which is not at all sure to be healthy". Some also mentioned the irresponsible taking of loans and credit, which they considered to be inappropriate.

Several respondents mentioned luxury and fashion products along with some negative associations attached to them: participants considered the consumption of such products expensive cars, mobile phones, clothes - to be unnecessary and wasteful.

\subsection{Aspects of purchase decisions}

Our responses revealed that the most important aspects considered in a purchase situation were price and quality. Several answers, however, included references to the appearance of the packaging or the store and the importance of friends' and acquaintances' opinions. Respondents, irrespective of their age, noted a twofold view of advertisements: several confessed that they had sometimes made purchase decisions based on advertisements. We found, however, that they do not trust ads but believe them to be a pig in a poke and to have an influence on their purchase decisions through their subconscious. In spite of all of the negative views on them, ads were considered as an important source of information about both companies and their products.

All three generations mentioned brands in their responses as a kind of guarantee and as a sign of quality. Brands had the most important role among young respondents and were less significant among elder people. Reliance upon brands was more apparent in the case of goods of higher value; people's attachment to brands was far weaker when everyday purchases were considered. 
Products of Hungarian origin seemed to appeal to all three generations. No generational differences were found concerning how information about the producer affects people's purchases. The participants thought that they were only influenced by such pieces of information if they were negative: "Once there was something like that about red pepper. We did not really buy red pepper from that company those days" Or "if it turns out that child workers are kept like slaves somewhere, let's say by a clothing company I used to buy from, well then I wouldn't buy from them any more". Information on the social responsibility and social activities of companies, however, were found to have a less significant influence on purchase decisions.

\section{Summary}

Consumption and purchases were basically investigated relative to four aspects structure, environment and individual and social influencing factors - along which we intended to analyse generational differences.

We analysed the role of consumption and shopping individuals' lives and at the same time, we attempted to identify the symbolic role that goods might play in self-expression. Questions in this section examined attitudes and experiences and their forms and roles related to consumption and shopping. Based on the associations, we concluded that respondents basically related to these two concepts of food and clothing items. Excise goods were mentioned rarely or not at all, even though they appeared several times in the stories told by the members of the youngest generation about their first shopping experiences during childhood. It was interesting that although purchases beyond one's basic needs were characteristic for nearly all generations, they were most frequently mentioned by the youngest age group. Respondents agreed that consumption and shopping have a much greater role now than they had in the past. They also believed that media and shopping malls make us buy more than we actually need.

Households have undergone serious changes, predominantly characterised by modernised living conditions and an increased level of consumption and purchases as a result of more abundant financial resources. Simultaneously, quality has started to play a more significant role and purchases, beyond one's basic needs also, are becoming more frequent. We also looked into how the quantitative and qualitative aspects of consumption and shopping - especially those of a moral nature as opposed to economic considerations - might be characterised and how they had changed with time. With the amount of consumption and purchases increasing, we expected respondents to give more emphasis to quality-related aspects and we also expected ethical considerations (beyond economic ones) to enter the picture. The interviews and our observations indicate, however, that purchase decisions are little influenced by information on the social responsibility and activities of producers. The aspects most important in the eyes of our respondents were price and quality, although they demonstrated a willingness to pay more for their favourite brands.

Our research project also aimed to clarify whether the consumption and shopping habits of individuals affect their social relationships. Our assumption was that social relationships are significantly influenced by the nature of the individual's consumption, which appears as a form of self-expression. The majority of respondents, however, reported that consumption and purchases do not influence their judgement of their relationships with others. The participants explained this by stating that the consumption 
and shopping patterns of their community, friends and acquaintances were rather similar in nature. Nevertheless, it was reported by several respondents that they had already been judged by their consumption habits or that at least they thought it was possible that one's consumption might have a positive or negative influence on their social relationships. Luxury and fashion products, the goods most suitable for self-expression, were observed to have generally negative associations attached to them. This was especially characteristic for the elder generation. There was no consensus between the various age groups concerning the acceptable limits of consumption and shopping. We found, after all, that more than half of our respondents thought that there was no such limit, which they primarily associated with individual consumption opportunities being determined by income. Moreover, several participants mentioned purchases beyond basic needs and the wasting of goods.

\section{References}

Bauman, Z. (2001) 'Consuming life', Journal of Consumer Culture, Vol. 1, No. 1, pp.9-29.

Dessewffy, T. (2002) Az Ántivilág. A Kocka el van Veszve [The Cube is Lost]. Budapest: InfoniaAula.

Douglas, M. and Isherwood, B. (1996) The World of Goods: Towards an Anthropology of Consumption. London: Routledge.

Flick, U.P. (2002) An Introduction to Qualitative Research. London: Sage.

Flick, U. (2005) 'Episodic interviewing', in M.W. Bauer and G. Gaskell (Eds.), Qualitative Researching with Text, Image and Sound: A Practical Handbook. London: Sage.

Ger, G. and Belk, R. (1999) 'Accounting for materialism in four cultures', Journal of Material Culture, Vol. 4, No. 2, pp.183-204.

Hammer, F. and Dessewffy, T. (1997) 'A fogyasztás kísértete' [The phantom of comsumption], Replika, Vol. 26, pp.31-46.

Hofmeister-Tóth, A. (2004) Fogyasztói magatartás [Consumer Behavior]. Budapest: AULA.

Hofmeister-Tóth, Á. and Töröcsik, M. (1998) Fejezetek a fogyasztói magatartás témaköréböl [Chapters of Consumer Behavior]. Budapest: AULA.

Keller, M. and Vihalemm, T. (2003) 'Return to the "Consuming West"', Young- Nordic Journal of Youth Research, Vol. 11, No. 3, pp.195-215.

Miller, D. (1999) A Theory of Shopping. Cambridge: Polity Press.

Nagy, S.K. (1997) 'Fogyasztás és lakáskultúra Magyarországon a hetvenes években’ [Consumption and interior decoration in Hungary in the 1970], Replika, Vol. 26, No. 2, pp.47-53.

Ritzer, G. and Slater, D. (2001) 'Editorial', Journal of Consumer Culture, Vol. 1, No. 1, pp.5-8.

Slater, D. (1997) Consumer Culture and Modernity. Cambridge: Polity Press.

Wessely, A. (2000) 'Utazó emberek, utazó tárgyak' [Travelling people, travelling objects], Replika, Vol. 39, pp.95-106. 